Jnl of Ecclesiastical History, Vol. 72, No. 2, April 202I. (C) The Author(s), 2021. Published by Cambridge University Press

This is an Open Access article, distributed under the terms of the Creative Commons Attribution licence (http://creativecommons.org/licenses/by/4.0/), which permits unrestricted re-use, distribution, and reproduction in any medium, provided the original work is properly cited.

doi:10.1017/Soo22046920002559

\title{
Stones of the Saints? Inscribed Stones, Monasticism and the Evangelisation of Western and Northern Britain in the Fifth and Sixth Centuries
}

\author{
by KEN DARK \\ University of Reading \\ E-mail k.r.dark@reading.ac.uk
}

Despite the paucity of written sources for fifth-and sixth-century Britain, there are many inscriptions containing brief texts in Latin or Irish. This paper reinterprets these inscribed stones, showing that, contrary to the universal current assumption that most represent the memorials of secular notables, a much stronger case can be made for understanding them as ecclesiastical monuments associated with the cult of saints. Read in this way, they offer new insights into the fifth- and sixth-century British Church and the evangelisation of the west and north of Britain during these centuries.

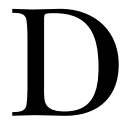

etailed historical understanding of the religious history of Britain between the visit of Germanus in 429 , usually considered to be the latest expedition by a continental churchman to what had until recently been Roman Britain, and the mission to the Anglo-Saxons led by Augustine of Canterbury in 597, might be supposed impossible due to the paucity of textual sources. As is well-known among scholars of British ecclesiastical history, this is a period in which widespread religious

$A C=$ Archaeologia Cambrensis; $C A=$ Cornish Archaeology; CMCS = Cambridge Medieval Celtic Studies; EME = Early Medieval Europe

In this article, inscriptions in Wales are cited according to the numbering system used in the recent Welsh corpus by Nancy Edwards, Mark Redknap and John Lewis, and inscriptions in south-west Britain are numbered according to Elizabeth Okasha's system. 
transformation occurred, yet one about which little is known beyond the broadest outlines of the process involved. However, while few written sources exist for Britain between about 400 and 6oo, there are many brief texts-exact numbers are debatable but over two hundred and forty - inscribed into stone (collectively known as inscribed stones) from across almost the whole of western and northern Britain. These inscribed stones have been extensively studied and published by scholars, demonstrating conclusively that most date to the fifth and sixth centuries. An online database of their texts has been established by the University College London Celtic Inscribed Stones Project, a corpus of the stones published for Wales and another for south-west Britain. ${ }^{1}$

Previous work has also shown that inscribed stones share common characteristics despite superficial visual differences between them. Their texts are usually either in Latin or both Latin and Irish, using Roman script alone or in combination with the ogam (also known as ogom or ogham) script widely used on its own in fifth- and sixth-century Ireland for Irish-language inscriptions. $^{2}$ A few ogam inscriptions in Britain are, like the Irish stones, in ogam alone. All the British inscriptions are on unshaped or roughly-shaped stones, usually showing evidence of having stood vertically in the ground, with texts laid out either horizontally (like Roman inscriptions) or vertically along the

${ }^{1}$ For the corpus of inscriptions with epigraphic and linguistic discussion see Nancy Edwards, A corpus of early medieval inscribed stones and stone sculpture in Wales, II: South-west Wales, Cardiff 2007; III: North Wales, Cardiff 2013, and 'New discoveries of early medieval carved stones in Wales', $A C$ clxv (2016), 187-99; Charles Thomas and Katherine Forsyth, 'An ogam inscription from Paul, West Penwith', CA liv (2015), 205-17; T. M. Charles-Edwards, Wales and the Britons, 350-1064, Oxford 2013, 96-178, 188, 235-7; M. Redknap and J. M. Lewis, A corpus of medieval inscribed stones and stone sculpture in Wales, I: South-east Wales and the English border, Cardiff 2007; C. Tedeschi, Congeries lapidum: iscrizioni Britanniche dei secoli V-VII, Pisa 2005; Michael Fulford, Mark Handley and Amanda Clarke, 'An early date for ogham: the Silchester ogham stone rehabilitated', Medieval Archaeology lxiv (2000), 1-23; Charles Thomas, 'A supplement to "Corpus of Early Christian inscribed stones of south-west Britain" by Elisabeth Okasha: some comments, a correction and an addition', CA xxxix-xl (2000/2001), 39-40; and Elizabeth Okasha, Corpus of early Christian inscribed stones of south-west Britain, Leicester 1993, and 'A supplement to "Corpus of early Christian inscribed stones of south-west Britain", CA xxxvii-viii (2003), 137-52. The UCL Celtic Inscribed Stones database is at <https://www.ucl.ac.uk/archaeology/cisp/database/ $>$. Note that there is no reason to suppose that the two re-used inscriptions on stone from Tintagel Head in Cornwall, while of similar date, were from inscribed stones in the sense discussed here or even funerary in intent: Okasha, 'Supplement', 142-4; R. C. Barrowman, C. E. Batey and C. D. Morris, Excavations at Tintagel Castle, Cornwall, 1990-1999, London 2007, 99; <https://www.englishheritage.org.uk/visit/ places/tintagel-castle/history-and-legend/collection/>.

${ }^{2}$ P. Sims-Williams, The Celtic inscriptions of Britain: phonology and chronology, c. $400-$ I 200 , Oxford-Boston, Ma 2003. 
stone pillar. Although a few remain in what is probably their original position, most have been moved either for re-use or safe-keeping.

The inscriptions record the names of one or more individuals, often indicating a family relationship between them with terms such as fili (son of) or filia (daughter of), the former being much more common. Occasionally, they bear Christian symbols, usually the chi rho or cross, ${ }^{3}$ and their inscriptions often employ memorial formulae associated with fifth- and sixthcentury Christian tombstones in continental Europe, known from Italy to Gaul and Spain. 4 These formulae attest that at least some of the British stones also marked places of Christian burial, containing Latin phrases such as hic iacet (often misspelt iacit) ('here lies') or in hoc tumulo ('in this tomb'). Recent work suggests that they might have combined this funerary role with a secondary function as statements of land-ownership or boundary- or way-markers, 5 the former possibly explaining the use of the genitive for the personal names on the majority of these inscriptions. ${ }^{6}$

As most archaeologically-excavated western and northern British cemeteries of the same period have no such inscriptions, 7 they were probably reserved for a small number of people. Consequently, it is usually proposed that they were the burial markers of important secular and ecclesiastical individuals, especially perhaps the former. ${ }^{8}$

This paper presents an alternative interpretation of these inscriptions, taking account of all that is known about their content, physical form

3 Edwards, North Wales, 66-7; Ken Dark, 'Epigraphic, art-historical and historical approaches to the chronology of class I inscribed stones', in Nancy Edwards and Alan Lane (eds), The early Church in Wales and the West: recent work in early Christian archaeology, history and place-names, Oxford 1992, 51-61.

4 Mark Handley, 'The origins of Christian commemoration in late antique Britain', EME x/2 (2001), 177-99; David Petts, 'Burial in western Britain, AD 400-80o: late antique or early medieval?', in Rob Collins and James Gerrard (eds), Debating late antiquity in Britain, $A D$ 300-70o Oxford 2004, 77-87; Jeremy Knight, 'In tempore Iustini consulis: contacts between the British and Gaulish Churches before Augustine', in Alec Detsicas (ed.), Collectanea historica: essays in memory of Stuart Rigold, Maidstone 1981, 54-62; Jeremy Knight, 'The early Christian Latin inscriptions of Britain and Gaul: chronology and context', in Edwards and Lane, The early Church in Wales and the West, 45-50; J. Knight, The end of antiquity: archaeology, society and religion, $A D$ 235-70o, Stroud 1999.

5 Nancy Edwards, 'Early-medieval inscribed stones and stone sculpture in Wales: context and function', Medieval Archaeology xlv (2001), 15-39; Edwards, South-west Wales, 34; Mark Handley, 'The early medieval inscriptions of western Britain: function and sociology', in Joyce Hill and Mary Swan (eds), The community, the family and the saint: patterns of power in early medieval Europe, Turnhout 1998, 339-61, and 'The origins of Christian commemoration in late antique Britain', $E M E \mathrm{x} / 2$ (2001), 1 77-99.

6 Handley 'Early medieval inscriptions', 347-9.

7 For examples see David Longley, 'Early medieval burial in Wales', in Nancy Edwards (ed.), The archaeology of the early medieval Celtic churches, Leeds $2017,105^{-14}$, $116-18$.

${ }^{8}$ Charles-Edwards, Wales, 141; Handley, 'Early medieval inscriptions', 358-9. 
and location, and the contemporary political and religious context in which they were erected. In order to do so it is first necessary to examine evidence for the secularity of those commemorated by their inscriptions, given the dominance of a secular interpretation for most of the stones.

\section{Evidence for secularity}

No contemporary textual source directly mentions these inscribed stones, and the much later medieval Welsh laws refer only to boundary stones, 9 which might have been uninscribed, rather than to inscriptions. Although Irish textual evidence has been used as an analogy for their secularity and function, ${ }^{10}$ the earliest relevant Irish texts date to the seventh century and are legal references to the function of ogam stones as statements of land-ownership, without comment on whether the land being marked in this way, or the ogam stones, belonged to secular individuals or communities. Given that these legal texts concern the use of ogam stones in a different island and a different century to the ogam inscriptions in Britain, none of which on linguistic grounds is likely to post-date the sixth century, their relevance to the interpretation of ogam inscriptions in Britain, let alone all inscribed stones, is doubtful.

Only in Irish literary sources, notably the Ulster Cycle, ${ }^{11}$ are ogam stones mentioned as the tombstones of secular-but literary and legendaryfigures. This is obviously also inadmissible as evidence for the secularity of inscribed stones in Britain on several grounds: the literary character of the texts, its later date than ogam stones in Britain, and its reference only to specific areas within Ireland and never to Britain. Furthermore, as Charles Thomas observed, ${ }^{12}$ because ogam is a script rather than an ideological statement it could be used in different places for different purposes at different times.

This leaves only the internal evidence of the inscribed texts and their archaeological and landscape contexts as evidence for the secularity of those mentioned on the stones. It might be claimed that this is demonstrated by references to men whose names contain elements meaning 'prince' or 'king', make reference to heroic virtues, or include elements derived from fierce animals inappropriate to clergy. Such arguments can easily be discounted. Just because someone's name contained a reference

9 Handley, 'Early medieval inscriptions', 340-1.

${ }^{10}$ Ibid. $340-5$.

${ }^{11}$ Ibid. $345^{-6}$. For textual references see D. McManus, A guide to ogam, Maynooth $1991,163^{-6 .}$.

${ }_{12}$ A. C. Thomas, And shall these mute stones speak? Post-Roman inscriptions in western Britain, Cardiff 1994, 73. 
to royalty is insufficient in itself to identify them as royal, as the many recorded names of this sort from first millennium AD Britain and Ireland show. ${ }^{13}$ Even if these names do indicate royal or aristocratic status, clerics might have retained the name given to them at birth, reflecting the cultural values of their family or expectations concerning their social role, rather than their adult life. This is directly attested in sixth-century western Britain by Gildas's description of Maglocunus, who was both a monk and a king successively, yet who retained a suitably heroic name for a warrior king. ${ }^{4}$ Examples can be found throughout Insular societies and more widely of kings and other high-ranking secular individuals entering monastic life in the period broadly contemporary with the inscriptions. ${ }^{15}$

There are just two certainly secular titles in any of these inscriptions: a king (rex), Catamanus (AN26), generally accepted to be the Cadfan of the Welsh genealogies, an early seventh-century king of Gwynedd, ${ }^{16}$ and the principes Nudus and Dumnogenus, mentioned on an inscription from Yarrow Kirk. ${ }^{17}$ Although it was once claimed that the Voteporigis mentioned on the Castell Dwyran inscription $\left(\mathrm{CM}_{3}\right)$ was Gildas's Vortepor, king of the Demetae (Dyfed, in south-west Wales), philological scholarship has shown that these are different names. ${ }^{18}$ Even the inscriptions directly mentioning royalty may be far less secular than they seem. The use of sapientissimus (wisest) on Catamanus' tombstone was usually reserved for clerics, ${ }^{19}$ and the stone also has a prominent cross symbol. The use of memoria on the Yarrow Kirk stone suggests a martyrial burial, the term being used in this specific sense in the broader late antique epigraphy with which the British inscriptions share their formulae. ${ }^{20}$ Death by

13 For British and Irish examples from the first millennium AD see Sims-Williams, The Celtic inscriptions of Britain, and R. G. Collingwood and R. P. Wright (eds), Roman inscriptions in Britain, Oxford 1965 .

${ }^{14}$ Gildas, The ruin of Britain and other works, ed. and trans. M. Winterbottom, 2nd edn, Chichester 2002, ii. 34; Kenneth H. Jackson, 'Varia 2: Gildas and the names of the British princes', CMCS iii (1982), 30-40.

${ }^{15} \mathrm{~L}$. Alcock, Kings and warriors, craftsmen and priests in northern Britain, AD 550-85o, Edinburgh 2003, 35 .

16 Edwards, North Wales, $180-3$.

${ }^{17}$ Charles Thomas, 'The early Christian inscriptions of southern Scotland', Glasgow Archaeological Journal xvii (1991), 1-10, no 9.

18 Edwards, South-west Wales, 202-6.

19 Idem, North Wales, 182; T. M. Charles-Edwards, Early Christian Ireland, Cambridge 2000, $264-71$.

${ }^{20}$ For saints' tombs and their terminology in late antiquity see John Bryan WardPerkins, 'Memoria, martyr's tomb and martyr's Church', Journal of Theological Studies xvii (1966), 20-37, and F. W. Deichmann, Rom, Ravenna, Konstantinopel, Naher osten: gesammelte Studien zur spätantiken Architektur, Kunst und geschichte, Wiesbaden $1982,375^{-400}$. For the use of memoria in British inscriptions of this period, and the specific meaning of those terms in that context see Edwards, South-west Wales, 42, and 
martyrdom might also explain the simultaneous burial of two related individuals, although this could, of course, have occurred for other reasons such as plague or battle.

The remainder of the apparent evidence for secularity is equally problematical. For example, an individual was commemorated at Clocaenog (D1) as tovisaci ('prince, leader'), but again whether this is a title rather than a personal name ${ }^{21}$ is far from certain and it is impossible to be sure whether this man died as a secular notable or an ecclesiastic. Other apparently secular epithets on the inscriptions, such as figulinus (CN29), might also have been names rather than titles, especially as figulinus (meaning 'belonging to a potter') was commemorated in a context where there is unlikely to have been local pottery production. ${ }^{22}$ Terms indicating specialists such as fabri ('smith') ${ }^{23}$ or medicus ('doctor') at Llangian (CN25) could again have been used as personal names or might as easily be accommodated in a monastic context as a secular one. ${ }^{24}$ None of these apparently occupational terms, therefore, demonstrate conclusively that the person mentioned was part of lay society.

It is also noticeable that, in general, the names recorded in the many British royal genealogies ${ }^{25}$ are absent from the inscribed stones. While it

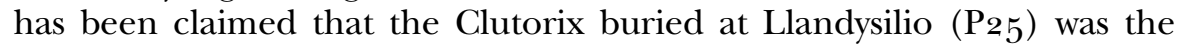
Clotri of the Demetian king-list, ${ }^{26}$ the inscription and genealogy give different patronyms and it is more likely that these were separate individuals. ${ }^{27}$ This lack of overlap between the surviving written genealogies and the names on the inscribed stones (except for Catamanus) is highlighted by the inscription on the Bodvoc stone from Margam Mountain (G77), giving a three-generation genealogy unrecorded in any textual source.

The name Brychan, that of the eponymous founder of the kingdom of Brycheiniog, ${ }^{28}$ does occur in the form Brocagnus on two inscribed stones, but the same Brychan was also considered a prominent saint in medieval Wales, even the saintly father of a family of saints ('the children of Brychan') whose dedications are widespread around the Irish Sea. ${ }^{29}$ One of the inscribed stones bearing the name Brocagnus comes from a parish with a medieval church dedicated to a member of this family of

C. Thomas, The early Christian archaeology of north Britain, Oxford-Glasgow-New York $1971,105^{-6 .}$

${ }_{23}$ Okasha, Corpus, 278-80.

${ }^{21}$ Edwards, North Wales, 54-5.

22 Ibid. 55, 288-9.

24 K. Dark, Britain and the end of the Roman Empire, Stroud 2000, 177.

25 P. C. Bartrum (ed.), Early Welsh genealogical tracts, Cardiff 1966.

26 Thomas, And shall these mute stones speak, 62.

${ }^{27}$ Heather James, 'Llandysilio church and parish, 500-1 543: from heartland to borderland', Carmarthenshire Antiquary xxxiii (1997), 5-26.

${ }_{28}$ A. Lane and M. Redknap, Llangorse crannog: the excavation of an early medieval royal site in the kingdom of Brycheiniog, Oxford 2019, 408.

29 D. Petts, The early medieval Church in Wales, Stroud 2009, 130. 
saints, at St Endellion in Cornwall. $3^{\circ}$ Neither St Endellion, nor Llangeler in south-west Wales-where the other inscription containing the name Brocagnus ( $\mathrm{CM}_{25}$ ) is located-are anywhere near the kingdom of Brycheiniog in mid-Wales. ${ }^{31}$ Consequently, if these inscriptions bear any relationship to the Brychan of later medieval texts, they are more likely to make reference to him as a saint than, at least primarily, as a king. Without Clotri, Brychan or, as seen earlier, Vortepor, the only king whose name occurs both in the genealogies and on the inscribed stones remains Catamanus, the symbolism and text of whose memorial could be taken as implying an especially close relationship with the Church. There is no other evidence suggesting that the genealogies and inscribed stones record any of the same individuals, nor any other evidence that they were the tombstones of laypeople. Of course, it could be claimed that the genealogies are incomplete, later edited to excise specific rulers, or fictional, but if so this adds nothing to the argument in favour of these inscriptions referring to secular individuals.

\section{Wives, mothers and children}

As their personal names show, most of the inscriptions commemorate men, and often also give their father's name, $3^{2}$ but it might be supposed that because a small number of the inscribed stones, for example those from Llangefni (AN39), Llansadwrn (AN45), Llanymawddwy (MR2o) and Pentrefoelas (D9), mention wives, mothers and children. 33 this is evidence for the secularity of the individuals commemorated. However, this would be to project assumptions drawn from ecclesiastical practice elsewhere onto fifth- and sixth-century Britain in an unwarranted manner. Conclusively, the inscribed stone from Llansadwrn, Anglesey, specifically refers to a bishop's wife and that from Llantrisant $\left(\mathrm{AN}_{4} 6\right)$, also refers to the wife of a clergyman, calling her 'a most holy woman'. The references to wives in the inscriptions, therefore, offer no compelling evidence of secularity. Indeed, the inscriptions themselves show that clergy, even bishops, could be married in the British Church of this period.

$3^{\circ}$ Okasha, Corpus, 232.

$3^{1}$ Lane and Redknap, Llangorse, 405-6; K. Dark, Civitas to kingdom: British political continuity, 30o-80o, London 1993, 79, 81-3, 104, 118-19, 130-2, 134-5.

$3^{2}$ Redknap and Lewis, A corpus, 61-2.

33 Edwards, South-west Wales, 54; David Petts, 'Burial and gender in late and subRoman Britain', in Colin Forcey, John Hawthorne and Rob Witcher (eds), TRAC 97: proceedings of the seventh annual theoretical Roman archaeology conference, Nottingham I997, Oxford 1998, $112-24$. 
The few women commemorated alone might either have been important in secular society or have been female ecclesiastics, perhaps nuns. 34 Consequently, these and specific references to women as daughters on the inscribed stones from Eglwys Gymyn $\left(\mathrm{CM}_{7}\right)$ and Trawsfynydd (MR22) need mean only that after entering religious life women continued to be referred to by their patronyms in a society in which this was conventional. Likewise, while the inscriptions from Llanerfyl $\left(\mathrm{MT}_{4}\right)$ and Carnsew 35 show that at least two of the women commemorated were what today would be termed teenagers, this gives no guarantee of secularity in a period which recognised saints and martyrs in their teens. Alternatively, those commemorated could have been very young nuns. Likewise, although the inscription from Spittal (P136) mentions a mother, it is as the joint memorial of a mother and son, a man whose social position, and therefore secularity, is unknown.

Consequently, the presence of wives, mothers and children in the inscriptions, while interesting, is also insufficient to necessitate a secular interpretation of these memorials. Conversely, it could equally well attest the presence of married clergy, the existence of nuns and the veneration of female saints.

\section{Evidence for ecclesiastics}

Having examined all of the evidence from the inscriptions for secularity, it is logical next to see if there is any evidence that these monuments commemorate ecclesiastics. Many of the inscriptions use either symbols or formulae indicative of Christianity in the context of fifth-century burial practices elsewhere, such as hic iacet (often in Britain inscribed as hic iacit) or in hoc tumulo. $3^{6}$ More rarely, there are unambiguously Christian phrases, such as te dominum laudamus ('We praise you Lord') on the Latinus stone from Whithorn.37 Although these memorial formulae and symbols may show only that the stones carrying them were inscribed in a Christian context, and probably for Christians, a minority of stones also have texts directly indicating that they were the memorials of clerics. For example, the terms subdiaconus ('sub-deacon'), presbyter ('priest') and sacerdotes ('priests') are all found, and others may also carry less obvious clerical

34 Nuns are mentioned in Insular sources as early as the fifth century: St. Patrick, his writings and Muirchu's Life, ed. and trans. A. B. E. Hood, Chichester 1978, 7, $5^{\circ}$.

35 Thomas, And shall these mute stones speak, 190-4; Okasha, Corpus, 116.

$3^{6}$ Edwards, South-west Wales, 41-2; Jeremy K. Knight, 'An inscription from Bavai and the fifth-century Christian epigraphy of Britain', Britannia xli (2010), 283-92.

37 Katherine Forsyth, 'Hic memoria perpetua: the early inscribed stones of southern Scotland in context', in Sally Foster (ed.), Able minds and practiced hands, London 2017 , $113-34,3^{6 .}$ 
meanings, such as in principi Iurici Audeti at Sourton, where princeps is probably best understood in its Insular Latin sense of 'abbot', $3^{8}$ or Emereto, strictly meaning 'veteran' but here probably denoting a cleric, at Nevern $\left(\mathrm{P}_{71}\right) .39$

The stone from Cardinham, known as the Tawna stone, $4^{\circ}$ exhorts 'orate pro episcopus Tito' ('pray for bishop Titus'), while that at Llandudno (CN2 1$)$ records Sanctinus the priest. Priests are also mentioned in what may be a monastic context at Capel Anelog $\left(\mathrm{CN}_{2}, \mathrm{CN}_{3}\right)$, where two inscriptions refer to Veracius the priest and Senacus the priest respectively, the latter buried with 'multitudinem fratrum' ('a multitude of brothers'), presumably monks. A priest named Paulinus is recorded in a long inscription at Llantrisant ${ }^{4}{ }^{1}$ and another Paulinus was commemorated at Cynwyl Gaeo, near Dolaucothi $\left(\mathrm{CM}_{5}\right)$, on a lengthy inscription probably originally reading 'servatur fidaei patrieque semper amator hic Paulinus iacit cultor pientisimus aequi' ('Preserver of the Faith and always lover of his homeland, here lies Paulinus the most devout supporter of righteousness'). Although there is no direct reference to his clerical status, plainly this Paulinus is presented here as a committed Christian, and such an interpretation is possible.

In northern Britain, Cross Kirk, Peebles, has two stones: one inscribed 'locus sancti Niniavi' and the other 'Neitano sacerdos', the first apparently uniquely indicating a consecrated place rather than an individual, the second recording a priest. $4^{2}$ It has also been suggested that the name Mailisi ('bald one'), on an inscribed stone at Llanfaelog (AN13), should be read as indicating a tonsured monk. 43

Some of the inscriptions may also use symbolic family relationships in an ecclesiastical context. The 'fili Martini' ('son of Martin') at Llangian (CN25) and the 'fili[a] Victri[c]i' ('daughter of Victricius') on the socalled Catstane near Edinburgh, refer perhaps to the great monastic leader Martin of Tours and to Victricius, one of his close associates. 44 Although the two people commemorated are unlikely to have had any direct relationship with either Martin or Victricius, of course, and the inscriptions recording them are more likely sixth century in date than earlier, filiation may have been used on these stones to indicate participation in, or at least sympathy with, monastic life. Again, it is notable that one of those commemorated may have been a nun.

$3^{8}$ Okasha, Corpus, 460.

39 Edwards, South-west Wales, 394.

$4^{\circ}$ Okasha, Corpus, 288.

$4^{1}$ Nancy Edwards, 'Christianising the landscape in early medieval Wales: the island of Anglesey', in Tomás Ó Carragáin and Sam Turner (eds), Making Christian landscapes in Atlantic Europe: conversion and consolidation in the early Middle Ages, Cork 2016, 178-203 at pp. 192-3.

43 Edwards, North Wales, 165. $4^{2}$ Thomas, 'Early Christian inscriptions', 2, 7. 44 Dark, Britain, 177, 203. 
Other inscriptions also use terms, such as memoria at Castell Dwyran and nomena (relics) $\left(\mathrm{P}_{10} \mathrm{O}_{7}\right)$ at St Davids, with a specific ecclesiastical meaning in this period. 45 It was probably British use of the latter that prompted Irish speakers in this period to adopt the equivalent formula anm ('name'). $4^{6}$ A few personal names on inscribed stones even occur as the dedications of the medieval churches at, or near, where they were found, such as Saturninus $\left(\mathrm{AN}_{45}\right)$ at Llansadwrn or Cunignus $\left(\mathrm{CM}_{7}\right)$ at Eglwys Gymyn. 47

It has long been suggested that the occurrence of single personal names without reference to filiation might be indicative of monastic practice, $4^{8}$ although this is uncertain. The analogous use of a single name in the genitive case is also found on monolingual ogam stones in Ireland and what seem linguistically to be the earliest ogam inscriptions in Britain.49 Consequently, the use of single names in the genitive on British Latin inscriptions may be in emulation of that practice, and like their ogam counterparts indicate 'the place of' the person named. $5^{\circ}$ While this could indicate secular ownership, as usually supposed, it is equally possible that ownership could be understood in an ecclesiastical sense, the place 'belonging' to a person of religious rather than secular distinction.

Taking all the available evidence for the social identity of those commemorated into consideration, it is, therefore, certain that several inscriptions commemorate ecclesiastics but none necessarily need to have commemorated individuals because of their secular rank alone. The only other arguments which might be forwarded against interpreting all of the British inscribed stones as ecclesiastical monuments are analogy with similar inscriptions in different contexts, both in Britain and overseas, or with reference to the archaeological context of the inscribed stones. It is these comparisons which form the next part of this paper.

\section{A non-lapidary analogy: the Rhuddgaer inscription}

Only one inscription similar in language, lettering and formula is known from Britain on any medium other than stone. Texts reading Camuloris

45 For memoria, see n. 19 above. The use of nomena for relics is discussed in Edwards, South-west Wales, 42, and Thomas, Early Christian archaeology, 105-6. For these inscriptions see also Heather James, 'Early medieval Pembrokeshire, AD 400-1100', in Heather James, Mary John, Kenneth Murphy and Geoffrey Wainwright (eds), Pembrokeshire county history, I: Prehistoric, Roman and early medieval Pembrokeshire, Haverfordwest 2016, 340-512.

$4^{6}$ C. Swift, Ogam stones and the earliest Irish Christians, Maynooth 1997, 85, 88-90, 1 26-7; Joseph Vendryes, 'Sur un emploi du mot ainm "nom” en irlandais', Etudes celtiques vii/ 1 (1955), 139-46.

47 James, 'Early medieval Pembrokeshire', 418.

$4^{8}$ V. E. Nash-Williams, Early Christian monuments of Wales, Cardiff 195o, 6.

49 J. Knight, South Wales from the Romans to the Normans: Christianity, literacy and lordship, Stroud 2013,65 . $5^{\circ}$ Handley, 'Early medieval inscriptions', 347-9. 
hoi and Camuloris were cast into two sheets of lead found at Rhuddgaer on Anglesey, $5^{1}$ probably from a rectilinear container or coffin. The precise context of the Rhuddgaer find is unknown but its association with a cemetery seems probable. Although it has usually been interpreted as part of a Roman-style lead coffin, this is uncertain and David Petts ${ }^{5}$ has persuasively argued that instead of a coffin the inscription could derive from a lead reliquary. Even if it is from a coffin, both the inscription and the use of, presumably costly, lead, could be understood as signifying a burial of special status. It may also suggest a context in which it was possible to read the inscription, such as display in a church or mausoleum. Consequently, rather than detracting from an ecclesiastical interpretation of the inscribed stones, the Rhuddgaer inscription might support it. Indeed, it may strengthen the association between inscriptions of this sort and the cult of saints, 53 evidenced elsewhere by the terms memoria and nomena.

\section{Analogies with inscriptions in Ireland and continental western Europe}

Another way of arguing against a wholly ecclesiastical interpretation of the inscribed stones might be by comparing the use of ogam in Britain with the many monolingual ogam stones of Ireland. 54 However, detailed analysis of the Irish ogam inscriptions by Cathy Swift and Damian McManus 55 has demonstrated a close relationship between the initial, fifth-century, use of ogam in Ireland and ecclesiastical contacts with Britain. As Christianity may be first attested textually in Ireland in about 400 , ogam is likely to have originated in the late fourth or early fifth century $5^{6}$ as a consequence

$5^{1}$ William W. Williams, 'Leaden coffin, Rhyddgaer', $A C \mathrm{xxx} / 4$ (1878), 136-40; Nash-Williams, Early Christian monuments, 59-61.

$5^{2}$ Petts, The early medieval Church, 103.

53 Richard Sharpe, 'Martyrs and local saints in late antique Britain', in Alan Thacker and Richard Sharpe (eds), Local saints and local churches in the early medieval West, Oxford 2002, $75^{-1} 54$.

54 James, 'Early medieval Pembrokeshire', 410-1 1; Edwards, South-west Wales, 34-41.

55 Muiris O'Sullivan and Liam Downey, 'Ogham stones', Archaeology Ireland cviii (2014), 26-9; Catherine Swift, 'Christian communities in fifth and sixth century Ireland', Trowel vii (1996), 21-32; Swift, Ogam stones; Fionnbarr Moore, 'The ogham stones of county Kerry', in Griffin Murray (ed.), Medieval treasures of County Kerry, Tralee 2010, 6-18, and 'Munster ogham stones: siting, context and function', in Michael A. Monk and John Sheehan (eds), Early medieval Munster: archaeology, history and society, Cork 1998, 23-32; D. McManus, The ogham stones at University College Cork, Cork 2004, and A guide to ogam, Maynooth 1991, esp. p. 41.

$5^{6}$ Anthony Harvey, 'Early literacy in Ireland: the evidence from ogam', CMCS xiv (1997), 1-15; McManus, A guide, 19-31. See also Patrick Sims-Williams, 'Some problems in deciphering the early Irish ogam alphabet', Transactions of the Philological Society xc/2 (1993), 133-80, and Erich Poppe, 'Writing systems and cultural identity: ogam in medieval and early modern Ireland', Language $\mathcal{E}$ History xvi/1-2 (2018), 
of missionary activity by Britons. 57 Swift has also argued on linguistic grounds that the majority of ogam-inscribed tombstones in Wales belong to the fifth, rather than later, centuries, and although she has so far left the ogam inscriptions of south-west Britain out of her analysis her arguments would apply to that area also. $5^{8}$ While it is curious that this script, rather than Latin, was used for monuments in fifth-century Ireland, even if ogam was used in fifth- and sixth-century Ireland only partly for ecclesiastical purposes, if it was introduced through ecclesiastical contacts with Britain this would allow the possibility that it had an exclusively ecclesiastical function in British epigraphy. Consequently, the close relationship between British inscribed stones and Irish ogam inscriptions provides no evidence that the former commemorate secular individuals.

There is no doubt that the Latin texts of British inscribed stones also contain characteristics found in the fifth- and sixth-century Christian funerary epigraphy of continental Europe. Examples include the use of memorial formulae such as memoria and hic iacet, common in Gaul, Italy and Spain at this time. 59 The Christian symbolism of the stones, such as the chi rho or ring-cross, ${ }^{60}$ and some of the personal names, such as Paternus or Martinus, are also found on these continental inscriptions.

However, there are important differences. The continental series of inscriptions, except for a few Breton examples, which are uniquely similar to those from Britain, were typically cut onto well-shaped flat slabs designed to lie flat on the ground rather than unshaped or roughly-shaped pillars standing vertically. ${ }^{61}$ They are never found as isolated wayside monuments and occur in much larger numbers, probably reflecting a wider social range. ${ }^{62}$ As Petts has shown, the verticality of the

23-38. On the earliest evidence for Christianity in Ireland see Donnchadh Ó Corráin, 'Orosius, Ireland, and Christianity', Peritia xxviii (2017), 113-34. For the funerary context of ogam in fourth- and fifth-century Ireland see Elizabeth O'Brien, 'Pagan or Christian? Burial in Ireland during the $5^{\text {th }}$ to 8th centuries AD', in Edwards, The archaeology of the early medieval Celtic churches, $135^{-54}$.

57 David N. Dumville, 'British missionary activity in Ireland', in David N. Dumville (ed.), St. Patrick, AD 493-1993, Woodbridge 1993, 133-45; Thomas M. CharlesEdwards, 'Britons in Ireland, c. 550-800', in John Carey, John T. Koch and Pierre-Yves Lambert (eds), Ildánach ilídrech: a Festschrift for Proinsias Mac Cana, Andover-Aberystwyth 1999, $15^{-26}$.

$5^{8}$ C. Swift, 'Welsh ogams from an Irish perspective', in Karen Jankulak and Jonathan M. Wooding (eds), Ireland and Wales in the Middle Ages, Dublin 2007, 62-79.

59 S. Pearce, South-western Britain in the early Middle Ages, London-New York 2004, ${ }_{1}^{15-7}$, 243, figure 103; M. Handley, Death, society and culture: inscriptions and epitaphs in Gaul and Spain, $A D$ 30o-75o, Oxford 2003, esp, ch. ii; Swift, Ogam stones, esp. p. 103.

60 Pearce, South-western Britain, 244-5; Dark, 'Epigraphic', 66-7.

${ }^{61}$ Handley, Death, society and culture, W. Davies, J. Graham-Campbell, K. Lockyear, M. Handley, P. Kershaw, J. T. Koch and G. Le Duc, The inscriptions of early medieval Brittany/Les Inscriptions de la Bretagne du haut moyen áge, Oakville, CT-Aberystwyth 2009. 62 Handley, Death, society and culture, $35^{-64}$. 
British stones was a deliberate decision rather than simply because they reused earlier standing stones, despite their superficial resemblance to prehistoric menhirs. ${ }^{63}$ The use of vertical pillars for British inscribed stones, unlike the continental series, must, therefore, be explained in terms contemporary with their inscriptions, perhaps by an intention to make these monuments highly visible-either in emulation of fifth-century ogam stones or as an independent innovation.

For these reasons, there is no doubt that the British inscribed stones represent a cognate, rather than identical, series of monuments to those of continental Europe, except for the Breton stones. As such, they may have had a different function to that of the continental series, while drawing on their language and epigraphical culture. Together, this suggests that the British stones are related to, but different from, both Irish ogam stones and the continental Christian tombstones with which they share memorial formulae and symbols.

Having considered possible analogies for the British inscribed stones as evidence for their secularity, only the archaeological context of the inscriptions remains as evidence that any were intended as memorials to secular individuals.

\section{Archaeological contexts implying secularity}

The few British inscribed stones remaining in situ are-excepting those found in long-cist cemeteries or other plausibly ecclesiastical contexts associated with routeways, as at Maen Madoc $\left(\mathrm{B}_{5} \mathrm{O}\right),{ }_{4}$ located at possible boundaries, in seemingly remote locations as at Men Scryfa, or on or adjacent to mounds or cairns, as at Boslow. ${ }^{6}$ Remote or wayside settings tell us nothing of the secularity or otherwise of the inscribed stones, but by comparison with Anglo-Saxon burial practices it might be imagined that mounds or cairns provide evidence for the secularity of the inscriptions. Nevertheless, this association is less straightforward than might initially be supposed.

Some of the mounds on which these stones stood are known to be wholly natural and others are certainly prehistoric. For example, the stone at Clocaenog (D1) was one of a pair, the other uninscribed, at the head and foot of what looks like a grave but is actually a natural mound. ${ }^{66}$ The placing of fifth- to seventh-century cemeteries at prehistoric monuments is well attested in western Britain, so their association with prehistoric

63 Petts, The early medieval Church, 136 ; Edwards, 'Early-medieval inscribed stones'.

64 Knight, South Wales, 67; Edwards, South-west Wales, 34.

65 Redknap and Lewis, South-east Wales, 135; Okasha, Corpus, 70; Thomas, And shall these mute stones speak, 291-4.

${ }^{66}$ Knight, 'An inscription from Bavai', $125^{-6 .}$ 
mounds or cairns may reflect that general practice rather than the secularity of the inscriptions. ${ }^{67}$ Nor need mounds or cairns necessitate secular commemoration. Graves of religious significance might also be marked by mounds or cairns, as illustrated by the cairn burial at Cannington (FT26), generally accepted as a religious focus within the cemetery. ${ }^{68}$ The only inscribed stone to mention a cairn in its inscription, the Carausius stone at Penmachno $\left(\mathrm{CN}_{3} 8\right)$, is also distinguished by a very prominent monogrammatic chi-rho cross symbol.

An alternative line of argument in favour of secularity might come from how the stones were later used. Inscribed stones incorporated in graves at Llannor (CN3o-1, perhaps also $\mathrm{CN}_{32}$ ) and Pentrefoelas (D9) could be taken as evidence for their being afforded scant value by subsequent generations and so, it might be claimed, more likely to be the memorials to secular individuals than those of religious distinction. However, there is no reason why a secular memorial should be treated in a different way to an ecclesiastical one: kings and aristocrats might fall from favour, but so might clergy. Nor need the incorporation of broken or whole inscribed stones in later burials imply disrespect for the memorials. Alternatively, it could be evidence for their use as relics, incorporated into graves to increase the likelihood of those buried going to heaven. It is, therefore, impossible to use the ways the stones were later reused as evidence for their secularity.

There is nothing, then, about the inscribed stones in terms of the content of their inscriptions, their original or secondary use, or the archaeological contexts in which they have been found, requiring that any of them need be secular memorials. All the direct evidence provided by the inscribed texts can be understood as relating to the commemoration of people of religious importance. Although only a minority of the inscriptions contain specific references to the occupation of the person commemorated, all those commemorated were, or could have been, assigned significance by the local Church.

\section{A new interpretation of the British inscribed stones}

To move from these observations to a new interpretation of the inscriptions it may be useful next to consider the context of their production. Recent epigraphic studies of the inscriptions have stressed the close relationship between their letter-forms and those of writing on other media, while

\footnotetext{
${ }^{67}$ For examples see Edwards, 'Christianising the landscape', $185^{-7}$; Edwards, 'Early medieval burial', 120; and Petts, The early medieval Church, 122.

${ }^{68}$ P. Rahtz, S. Hirst and S. M. Wright, Cannington Cemetery, London 2000, 51-7, $4^{1} 3^{-1} 4$.
} 
their formulae and symbolism attested familiarity with what were recent, or even contemporary, continental epigraphic practices. ${ }^{69}$ Their intended audience, or part of it, was also among those who could read their inscriptions, while references to priests, monks and bishops in the inscribed texts themselves might suggest an ecclesiastical context, which in fifth- to seventh-century western Britain is unlikely to have been urban, and was probably monastic. $7^{\circ}$ If so, the question is why monks would erect inscriptions to these people, especially when some of those inscriptions are in locations which are unlikely to have been inside their monasteries.

This draws attention to a further clue to the function of the stones: they were meant to be seen from a distance, as shown by their verticality andwhere it can be assessed-prominent siting, and also to be read by people approaching them. The memorial formulae emphasise that the stones mark either burial places or, by use of the genitive for the names on the stones, 'the place of' the person or people commemorated.

If these monuments were produced in a monastic context to indicate the burials or 'places' of people significant to them, including bishops and priests but also monks and nuns, then any interpretation must also take account of this. In fifth- and sixth-century Western Europe the most obvious group of people who would fit all of these criteria are those people who were considered saints by their contemporaries. Across Western Europe at this time, those venerated as saints could include young and old, men and women, and especially ecclesiastics, including monks. $7^{1}$ Wherever it occurred, the late antique veneration of saints needed focal places, where people could pray or engage in other devotional practices in honour of the saint or ask for their intercession.

A few inscriptions specifically include the terms sanctus (saint or holy person), nomena (relics) or memoria (martyrial shrine), all closely associated elsewhere with the cult of saints in late antiquity. The Rhuddgaer inscription might have been a reliquary, and the loaning of martyrium as merthyr into Welsh, *merther in Cornish and as moidir in Irish place-names in

69 Tedeschi, Congeries lapidum; Charles-Edwards, Wales, 1 16-29; John Higgitt, 'The stone-cutter and the scriptorium: early medieval inscriptions in Britain and Ireland', Epigraphik ccxii (1988), 149-62.

$7^{\circ}$ Charles-Edwards, Wales, 193-2 19, 637-8, 640-2. Secular literacy is also attested in this period, so literacy in itself is no guarantee of an ecclesiastical context: Dark, Civitas, 181 .

$7^{1} \mathrm{P}$. Brown, The cult of saints: its rise and function in Latin Christianity, Chicago 1981. For fifth-century western examples see R. Van Dam, Saints and their miracles in late antique Gaul, Princeton 2011. The use of ORATE PRO on the Tawna stone may refer in this context to the recommendation in Ephesians vi.1 8 to pray (to use the Vulgate translation) 'pro omnibus sanctis'. 
western Britain supports the interpretation that saintly shrines became widespread across the same general area as the inscribed stones. $7^{2}$

It might be supposed that the large number of individuals commemorated on the stones precludes such an interpretation. However, the myriad of local saints recorded in medieval church and holy well dedications in the west and north of Britain shows that local devotion to otherwise unknown saints, including both men and women, was a characteristic of these regions prior to the Norman Conquest. Likewise, that most stones record otherwise unknown names is explicable in terms of religious transformations over the centuries between our surviving medieval church dedications and the date of the inscriptions. Interpreting the inscriptions as monuments to saints, rather than as just the (or a) conventional form of ecclesiastical commemoration, also explains why only some ecclesiastics were commemorated in this way.

Saintly tombs might be expected in ecclesiastical establishments or cemeteries, as at the Catstane near Edinburgh 73 which seems to have had a focal role in cemetery development. By roadsides or at prominent local landmarks such as hills they could have served as places of prayer for travellers. Such monuments might also have been used, as other scholars have suggested, to assert land-ownership or to indicate territorial boundaries, whether those of church land or of monasteries' secular patrons. If inscribed stones marked saintly burials in isolated or wayside locations, then this may also explain why although many stones were found at the sites of later medieval churches many have no such association. 74

A characteristic of the analogous continental inscribed tombstones was that these 'became the physical embodiment' of the person commemorated and 'the above-ground focus for remembrance'.75 This may suggest that standing or kneeling in front of a British inscribed stone would, then, bring one into the perceived physical presence of the saint. The inscriptions themselves could, therefore, themselves have functioned as saints' shrines without the necessity of another structure.

Nevertheless, it is possible that some stones were originally part of built shrines, as perhaps at Penmachno $\left(\mathrm{CN}_{3} 8\right)$, where Carausius was buried 'in a heap of stones', perhaps analogous to the cairn excavated at Cannington. There, or at Carnsew, the cairn would offer pilgrims to a saintly shrine the opportunity to add or take away a small stone as part of their visit, perhaps in a similar way to that in which small stones were used for devotional practices at Irish pilgrimage sites. $7^{6} \mathrm{~A}$ more elaborate version of a shrine,

$7^{2}$ Pearce, South-western Britain, 139-141; Knight, The end of antiquity, 145.

73 Thomas, Early Christian archaeology, 54, fig 21.

74 Edwards, South-west Wales, 33. $\quad{ }_{75}$ Handley, Death, society and culture, 186.

$7^{6}$ R. Lash, 'Pebbles and peregrinatio: the taskscape of medieval devotion on Inishark Island, Ireland', Medieval Archaeology lxii (2018), 83-104. 
already interpreted by one of the excavators as a cella memoriae, was found at Beacon Hill, Lundy, 77 in a cemetery associated in general with no fewer than four inscribed stones. $7^{8}$

Consequently, interpreting the British inscribed stones as monuments intended for saintly devotion may explain the content of the inscriptions, the context of their production (as monasteries were closely associated with the veneration of saints, including their founders, across the world of late antiquity) and the presence of terminology meaningful only to literate Christians. It would also explain the locations in which these monuments are found and even - as relics rather than simply rubble - the way in which they could be incorporated into later graves. Furthermore, it might explain why these inscribed stones, unlike their continental counterparts, were, at least usually, freestanding pillars, which could have been visible from a distance rather than horizontal slabs.

\section{Implications for British ecclesiastical life in the fifth and sixth centuries}

Reinterpreting British inscribed stones in this way sheds greater light on the Church in fifth- to seventh-century Britain from textual (albeit epigraphic) sources than hitherto considered possible. The earliest of these inscriptions, perhaps among them those from Carnsew and Llanerfyl, may provide a terminus ante quem of the first quarter of the fifth century for the veneration of saintly burials in the west of Britain.79 To judge from the inscriptions, by the sixth century the cult of saints had spread to almost every part of the island where the Britons retained political control.

Both men and women were accorded saintly status, but the ecclesiastical offices mentioned on the inscriptions confirm the implications of Patrick and Gildas's writings, and of the British synods, ${ }^{80}$ that the British Church was organised in the same way as its fifth- and sixth-century continental counterpart, with regular ranks of male clergy from bishops to subdeacons. Nevertheless, in Britain, clergy, even bishops, could be married and their wives considered of religious merit.

It may also be possible to say something from epigraphic evidence of the social make-up of the ecclesiastical community. The personal names on the inscriptions fall into three categories. ${ }^{81}$ The first consists of Celtic names often indicative of patriliny (for example using Irish maqi or mac[c]u) or

77 Thomas, And shall these mute stones speak, 190-3, esp. figure 11.4.

$7^{8}$ Pearce, South-western Britain, figure 64; Thomas, And shall these mute stones speak, 163-82; Okasha, Corpus, 54-5. $\quad 79$ Knight, 'An inscription from Bavai', 289-9o.

80 The Irish penitentials, ed. and trans L. Bieler, Dublin 1963, 61-9.

81 This is discussed in detail in Sims-Williams, The Celtic inscriptions. 
heroic values such as bravery or generosity and/or containing royal or noble animal elements, both British and Irish in origin. The second uses standard late antique Latin names, often paralleled in Roman Britain, such as Paternus or Paulinus. The third group consists of names which might have been taken upon entering religious life, such as Sanctinus or Martinus. The first, and perhaps second, groups suggest a social origin for those commemorated among high-status groups, perhaps specifically the hereditary aristocracy. At least two stones record members of British royal families, possibly once in a monastic and once in a martyrial context.

Another aspect of ecclesiastical life illuminated by these inscriptions is the mobility of both those visiting the stones and those commemorated by them. Several inscribed stones were clearly positioned to be seen by travellers, including the Castell Dwyran inscription, that of Porius at Trawsfynnydd and the Latinus stone at Whithorn, all of which stand at nodal points in communication routes known from later centuries. ${ }^{82} \mathrm{~A}$ similar interpretation might account for the Elmetiaco, probably someone from Elmet, the area around Leeds in northern England, commemorated at Llanaelhaearn (CN2O) in north-west Wales. As Molly Miller noted, this was a place which was later a medieval station on the pilgrimage route to Bardsey Island and a trans-peninsular route across the Lleyn peninsula. ${ }^{83}$ On the few other inscriptions where territorial names are given, only one is certainly within the kingdom mentioned, again suggesting the mobility of those commemorated across fifth- and sixth-century political borders. ${ }^{8} 4$

In addition, many British inscribed stones record individuals with Irish names, ${ }^{85}$ and the north-west to south-east distribution of ogam-inscribed stones, bearing Irish names in an Irish script, in south-west Britain has long been proposed as a possible example of trans-peninsular travel, ${ }^{86}$ resembling that of Samson in the sixth century. ${ }^{87}$ If this is true of the south-west, it may be possible to see the presence of so many individuals with Irish names on inscriptions in Wales in terms of the widespread activity of Irish clerics rather than the migration of Irish warriors, as is usually assumed. This would fit well with other evidence suggesting a close relationship between the British and Irish Church in this period, and could explain

82 Katherine Forsyth, 'The Latinus Stone: Whithorn's earliest Christian monument', in J. Murray (ed.), St Ninian and the earliest Christianity in Scotland: papers from the conference held by the friends of the Whithorn Trust in Whithorn on September 15th, 2007, Oxford 2009, 19-41, esp. pp. 31-2.

${ }_{83}$ M. Miller, The saints of Gwynedd, Woodbridge 1978, 10.

84 Dark, Civitas, 110.

86 Dark, Civitas, 92-4.

87 For an important re-statement of the utility of the Vita Samsonis Prima as a source for this period see L. Olson (ed.), St Samson of Dol and the earliest history of Brittany, Cornwall and Wales, Woodbridge 2017. 
the pattern which Thomas ${ }^{88}$ noted of the repetition of personal names on inscriptions in south-west Wales and south-west England, reinterpreted here as representing the veneration of the same saints, or their namesakes, on either side of the Bristol Channel. The inscription from St Endellion discussed earlier may, in this context, really be a sixthcentury south-west British example of the cult of St Brychan, and if so, its earliest attestation.

Swift has noted that Irish ogam inscriptions provide possible epigraphic evidence suggesting the immigration of Latin-named, presumably British, individuals to Ireland in the fifth century, ${ }^{89}$ as is also attested in written sources. $9^{\circ}$ The British inscriptions may show that this was part of a twoway pattern of movement across the Irish Sea developing in the fifth and sixth centuries, with Irish clerics active in Wales, especially the southwest, and in what are today Cornwall and Devon. A possible ecclesiastical connection in this period between the south-west peninsula and southwest Wales has been identified on different grounds by Anne PrestonJones. $9^{1}$

The use of continental memorial formulae and symbols on these inscriptions also highlights the way in which the British Church was open to overseas contacts beyond the Insular world, much as the secular elite imported pottery and glass. $9^{2}$ Continental analogies of the formulae have long been used in chronological discussions about the inscriptions, 93 but the exact mechanism whereby word-perfect phrases were introduced into Britain has received little previous discussion. Unless one envisages epigraphic handbooks being brought to Britain, possibly suggested by the use of specific poetic forms at Cynwyl Gaeo $\left(\mathrm{CM}_{5}\right), 94$ the most plausible explanation is that either the inscriptions were composed by people who had actually seen the continental models and/or that their formulae were recorded in writing, perhaps on wax tablets.

Reinterpreted in this way, the British inscribed stones can be understood as memorials to people afforded saintly status by the monastic communities which produced the inscriptions. They provide evidence both for the

${ }^{88}$ Thomas, And shall these mute stones speak, 242, figure $15 \cdot 4$.

89 Swift, Ogam stones, $54^{-} 5$.

$9^{\circ}$ Charles-Edwards, 'Britons in Ireland'; Dumville, 'British missionary activity'.

$9^{1}$ A. Preston-Jones, 'Decoding Cornish churchyards', in Edwards and Lane, The early Church in Wales and the West, $105^{-24}$.

$9^{2}$ M. Duggan, Links to late antiquity: ceramic exchange and contacts on the Atlantic seaboard in the 5th to 7 th centuries $A D$, Oxford 2018; E. Campbell, Continental and Mediterranean imports to Atlantic Britain and Ireland, AD 40o-80o, York 2007.

93 Nash-Williams, Early Christian monuments.

94 Edwards, South-west Wales, 211 . If the use of the formulae and symbols derives wholly from imported epigraphic handbooks these must have been widely available to account for the surviving inscriptions. 
$25^{8} \quad$ KEN DARK

ecclesiastical culture of those communities and for clerical mobility within Britain and overseas. This combination of monastic communities, the cult of saints and an outward-looking perspective is widely found in the world of late antiquity. Elsewhere, it is associated with a specific role for monasteries as at the vanguard of converting rural populations to Christianity, evidenced from late fourth-century north-west Gaul to the sixth-century Holy Land.95 This may be the best explanation for the apparently rapid evangelisation of the west and north of Britain in the fifth and sixth centuries, where populations relatively untouched by the faith in the late fourth century had been comprehensively converted by the sixth.

95 R. Van Dam, Leadership and community in late antique Gaul, Berkeley-Los AngelesOxford 1992, 1 19-40; Doron Bar, 'The Christianisation of rural Palestine during late antiquity', this JOurnal liv (2003), 401-21, and 'Rural monasticism as a key element in the Christianization of Byzantine Palestine', Harvard Theological Review xcvii (2005), $49-65$. 